DOI: $10.5604 / 20830157.1130202$

\title{
PRACTICAL REALIZATION OF IDEAL DIODE FULL-WAVE RECTIFIERS
}

\section{Jiř́i Chytil}

Brno University of technology, Faculty of electrical engineering and communication, Department of Theoretical and Experimental Electronic Engineering

Abstract. This paper discuses practical realization of full-wave rectifiers made of electronic diodes for high current bipolar electronic loads. The presented solution minimizes the voltage drop and nonlinearity of loads in the region of low voltages. Compared to standard or Schottky diodes, electronic (also referred to as ideal) diodes exhibit very low voltage drop and power dissipation. In the full-wave rectifier, MOSFETs with very low RDSon (low units of milliohms) are used. Ideal rectifiers have been traditionally used as structural elements in switched power supplies; they are often applied in low dissipation power switches and started to be utilized as full-wave rectifiers.

Keywords: ideal diode, electronic diode, full-wave rectifier, MOSFET

\section{PRAKTYCZNA REALIZACJA IDEALNEGO PROSTOWNIKA DWUPOŁÓWKOWEGO}

Streszczenie. Artykut omawia praktyczna realizację prostownika dwupołówkowego wykonanego z użyciem diod prostowniczych dla obciązeń wysokoprądowych. Zaproponowane rozwiązanie minimalizuje spadek napięcia i nieliniowość obciązenia w zakresie matych napięć. W porównaniu do standardowej diody Schottkiego, diody „elektroniczne” (nazywane również idealnymi) wykazuja bardzo maty spadek napięcia $i$ straty mocy. W prostowniku dwupotówkowym użyto tranzystory MOSFET o bardzo niskiej $R_{D S o n}$ (rzędu miliomów). Idealne prostowniki sq tradycyjnie używane jako elementy konstrukcyjne $w$ zasilaczach impulsowych; sa one często stosowane $w$ niskostratnych przełacznikach mocy $i$ zaczynaja być stosowane jako prostowniki dwupotówkowe.

Słowa kluczowe: dioda idealna, dioda półprzewodnikowa, prostownik pełnofalowy, MOSFET

\section{Introduction}

In comparison with unipolar loads, bipolar electronic loads for high currents are very expensive and complicated devices. The working area of unipolar loads can be extended to the third quadrant via a full-wave rectifier (Fig. 1).

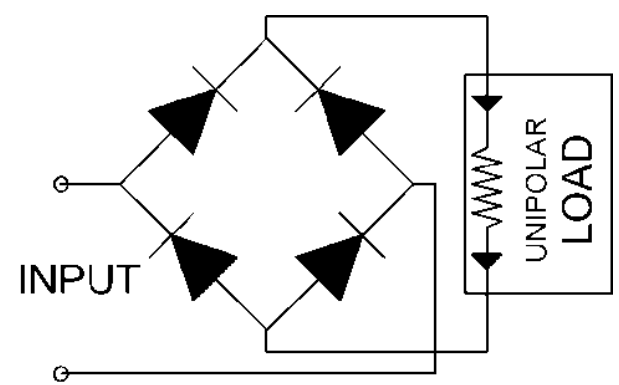

Fig. 1. Unipolar load with the working area extended to negative voltages

The main problem arises in the domain of low- input voltages. There is significant distortion (Fig. 2) caused by the use of conventional diodes and their voltage drops (1).

This article proposes new software that generates PWM signal for driving the fan speed. The software is composed of block memory for generating a triangular wave, data input coming from the digital temperature sensor and comparator for comparing between signals.

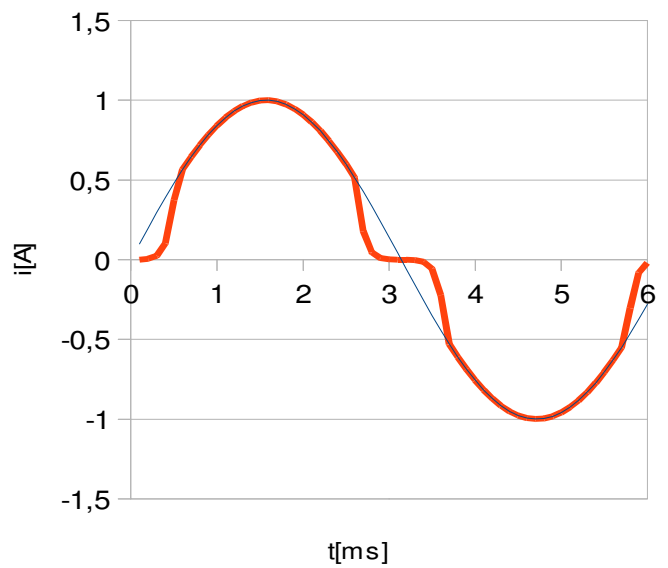

Fig. 2. Current distortion caused by diode voltage drop (red line), and the desired current waveform (blue)
Moreover, the voltage drop is doubled by the series connection of the diodes in the full-wave rectifier. If the load is used for low- voltage applications, the corruption of the signal is not negligible and can disallow usage of the load.

$$
I=I_{S}\left(e^{\frac{V_{D} q}{k T n}}-1\right)
$$

\section{Realization}

The problem indicated herein can be eliminated if the fullwave rectifier comprising conventional diodes is replaced with a full-wave rectifier composed of electronic (ideal) diodes [1].

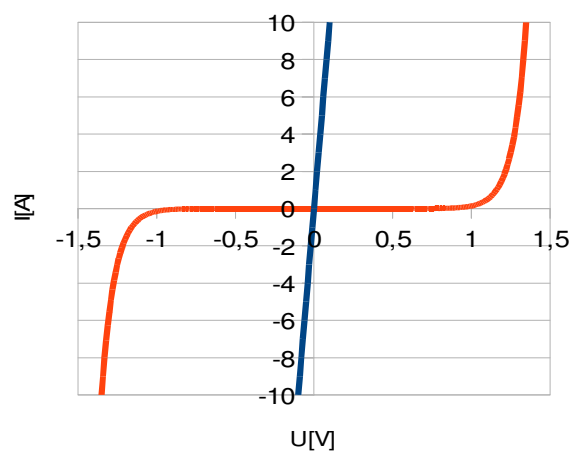

Fig. 3. Comparison of the VA characteristic of an "ideal" full-wave rectifier (blue), and the full-wave rectifier with conventional diodes (red)

The proposed solution minimizes the voltage drop and linearizes it (Fig. 3). Only the ohmic losses are present in the MOSFET channel. By choosing MOSFETs with very low RDSON, the voltage drop can be minimized to orders of millivolts per ampere [2].

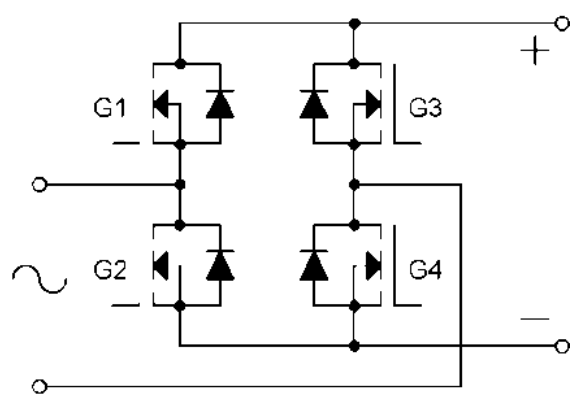

Fig. 4. Basic diagram of the FWR made of MOSFETs 
The internal diodes of MOSFET transistors used in a full-wave rectifier must follow the direction of the diodes in the conventional full-wave rectifier (hereinafter only FWR), (Fig. 4).
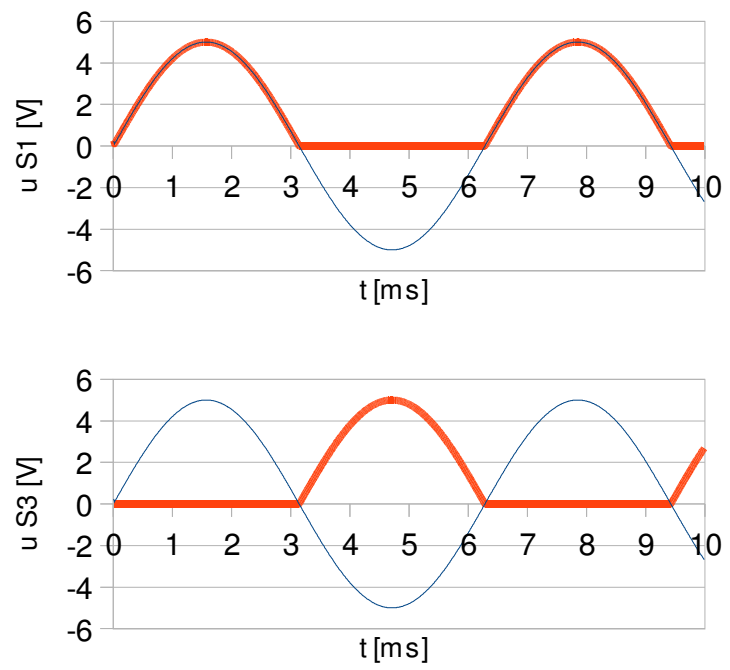

Fig. 5. Waveforms in the FWR; the reference for the red waveforms is negative output. The first waveform is the signal between the 1st and 2nd transistors, the second waveform is the signal between the 3rd and 4th transistors. The blue waveform is the original input signal between the input terminals

The system of MOSFET driving is based on waveforms in the corners of the FWR (Fig. 5).
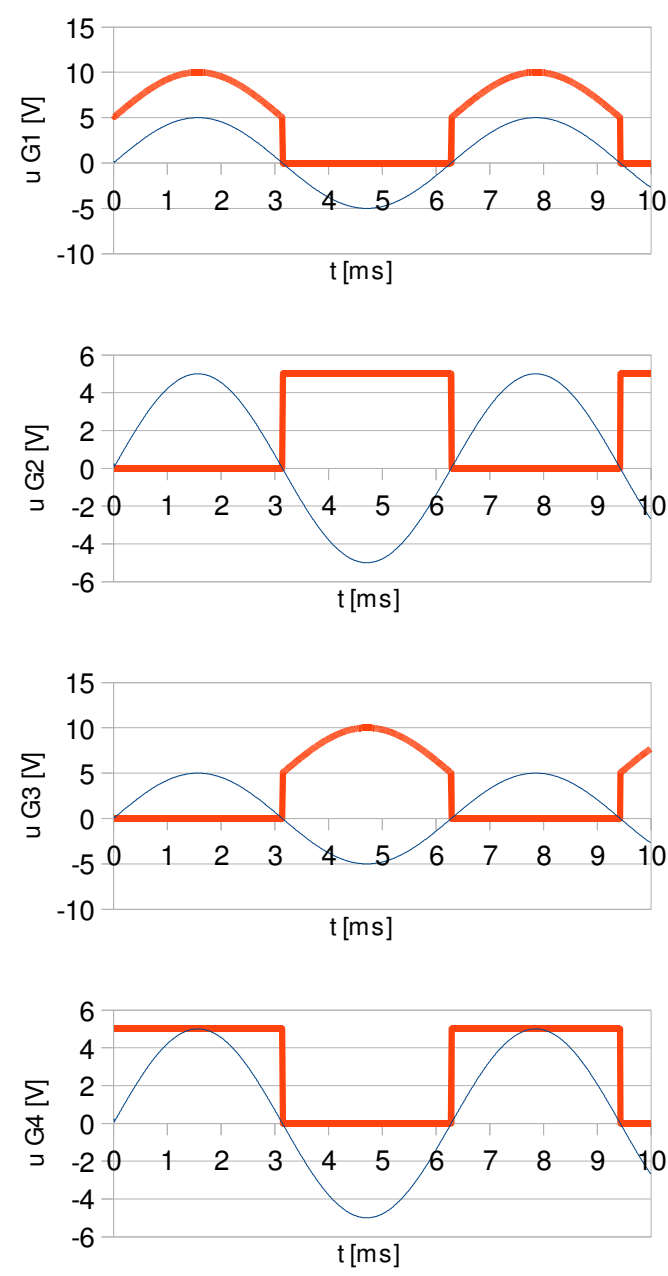

Fig. 6. Required gate voltages. The reference for the red waveforms is negative output. Upper pictures are driving signal for high-side MOSFETs and bottom for low-side MOSFETS.
The driving signal of the MOSFETs which have to be opened must be at least $5 \mathrm{~V}$ higher than the voltage on its SOURCE; the GATE voltage of the MOSFETs which have to be closed must be at a level equal to that of its SOURCE or lower (such situation is beneficial for shortening the recovery time).

But there are also disadvantages, for example the need to provide power supply to the rectifier, as shown in the image of gate voltages (Fig. 6).

There are commercially available integrated ideal full-wave rectifier drivers working up to $600 \mathrm{~Hz}$. From the range of Ideal Diode full-wave rectifier controllers, the types LT4320 and LT4320-1 were chosen. The controller LT4320 works up to $60 \mathrm{~Hz}$, and its advanced version LT4320-1 operates up to $600 \mathrm{~Hz}$. The diagram is indicated in Fig. 7.

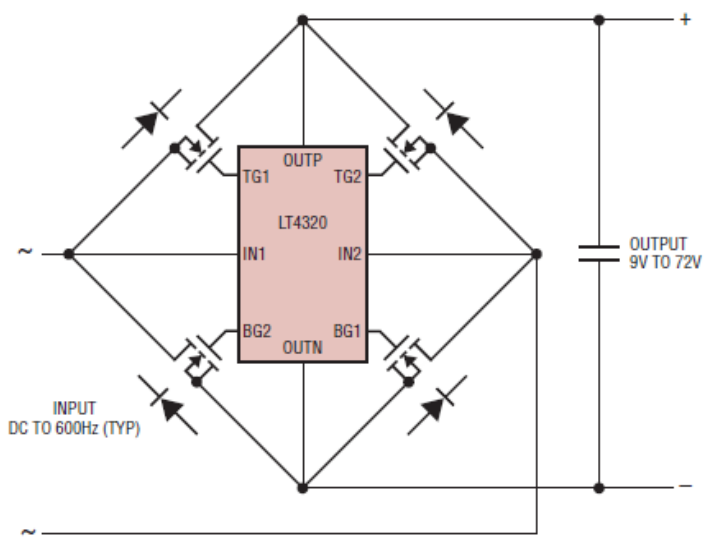

Fig. 7. Commeretial realization of FWR made of N-Channel MOSFET transistors [3]

However, the commonly designed full-wave rectifier is not suitable as a rectifier for electronic loads, because the circuit starts to work at 9 volts between the OUTP and OUTN pins. Below this voltage, the rectifying is performed by integrated MOSFET diodes. Then, another problem is that the controller compares the input and output voltage values. The expansion of the working area to the low level inputs thus cannot be solved by an external power supply.

The driver of the applied MOSFETs must be realized as a discrete solution due to the fact that the above-mentioned commercial integrated circuits cannot be used. The solution is realized as a comparator for the inputs which control the driving circuits for each of the MOSFETs. To achieve fast recovery time of the circuit, it is necessary not to work in deep saturation of the driving circuits.

The first part of the electronic FWR is a comparator. We utilize the feature that there cannot be negative voltage on the input of the comparator if the negative output is used as negative power for the comparator. The comparator has to be equipped with a rail-to-rail input or must be power-supplied by symmetrical voltage relative to the reference node (negative output voltage).

Commercial integrated half bridge drivers can be used as the MOSFET driver for high speed alternating current. Loads for low alternating current frequencies must be used in conjunction with special or discrete drivers. The solution of a driver for the low-side transistor is relatively simple. The elements concerned are a complementary bipolar transistor and an RC circuit. For the high-side transistor, there is also a complementary pair, but there also arises the necessity to modify the voltage level (Fig. 8).

\section{Realization of suitable full-wave rectifier driver}

There is need of suitable driver for full-wave rectifier. The main requirements are the generating correct driving signals for all of MOSFETs. It's also very important to make the signal with correct values of voltage to prevent damage of used 
MOSFET. We can use two solution of full-wave rectifier, one of them consist of four N-Channel MOSFETs and second feasible solution consist of two N-Channel MOSFETs at the bottom of FWR and pair of P-Channel MOSFETs as high side transistors of FWR. A shown in Fig. 10. There is another special demand: very important is not to load the source by driver.

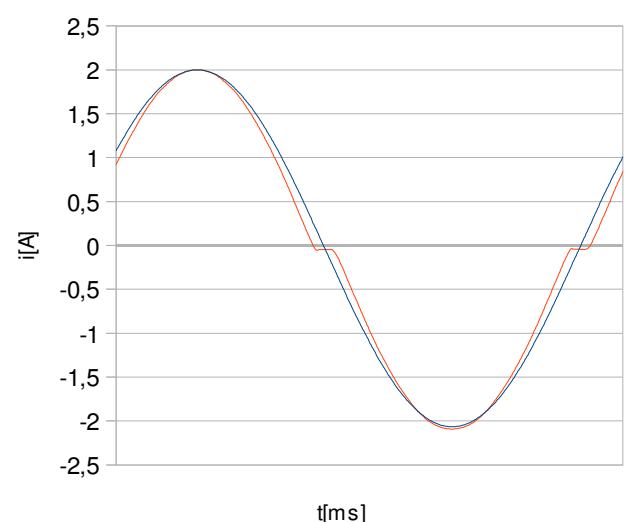

Fig. 8. Current distortion on the load. The red curve is for the conventional FWR, and the blue one is for the MOSFET FWR

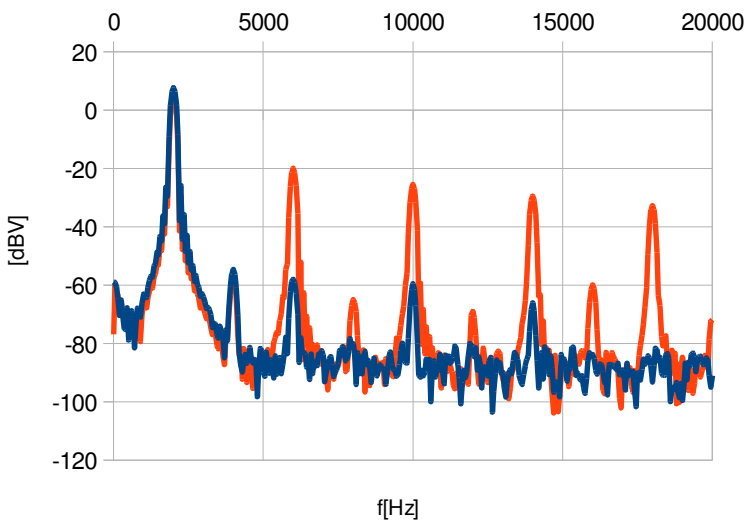

Fig. 9. Current spectrum on the load. The red curve is for the conventional FWR, and the blue one is for the MOSFET FWR

\section{Driver based on isolated drivers}

This solution uses fully isolated drivers (Fig. 11). Each of drivers utilizes power isolator realized by circuit ADuM5000 [4] $(U 2)$ configured as $5 \mathrm{~V}$ to $5 \mathrm{~V}$ isolator. For signal isolation there is circuit $\mathrm{ADuM} 3100[5](U 1)$. $\mathrm{ADuM} 3100$ is signal isolator for signals up to $1 \mathrm{Mbit} / \mathrm{sec}$ suitable with $3,3 \mathrm{~V}$ and $5 \mathrm{~V}$ logic. The output of isolator controls directly complementary couple of driving transistors $(Q 1, Q 2)$ which are used to generate signal for gate of transistor $Q$. The main advantage of this solution is simplicity and the reality that all of drivers are the same. For simplicity the capacitors in power lines are not shown. The main disadvantage of this solution is price caused by high price of insulators. The price can be almost halved by redesign of low side MOSFET's drivers. The low side drivers can use negative line of full-wave rectifier as reference line. So both isolators can be omitted.

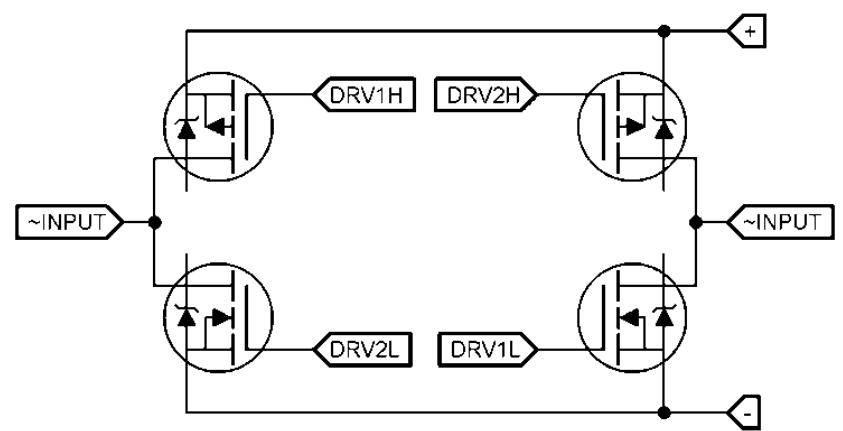

Fig. 11. Diagram of the FWR made of MOSFETs modified by changing N-Channel high side MOSFETS for P-Channel MOSFETS

\section{Solution based on buffered voltage}

This kind of solution is based on buffered input voltage (Fig. 12). It consists of two N-Channel MOSFETs as low side switches and two P-Channel MOSFETs as high side transistors. Driving of low side transistor remain the same as in driver based on isolated drivers $(Q 2, Q 3, D 1, R 3)$

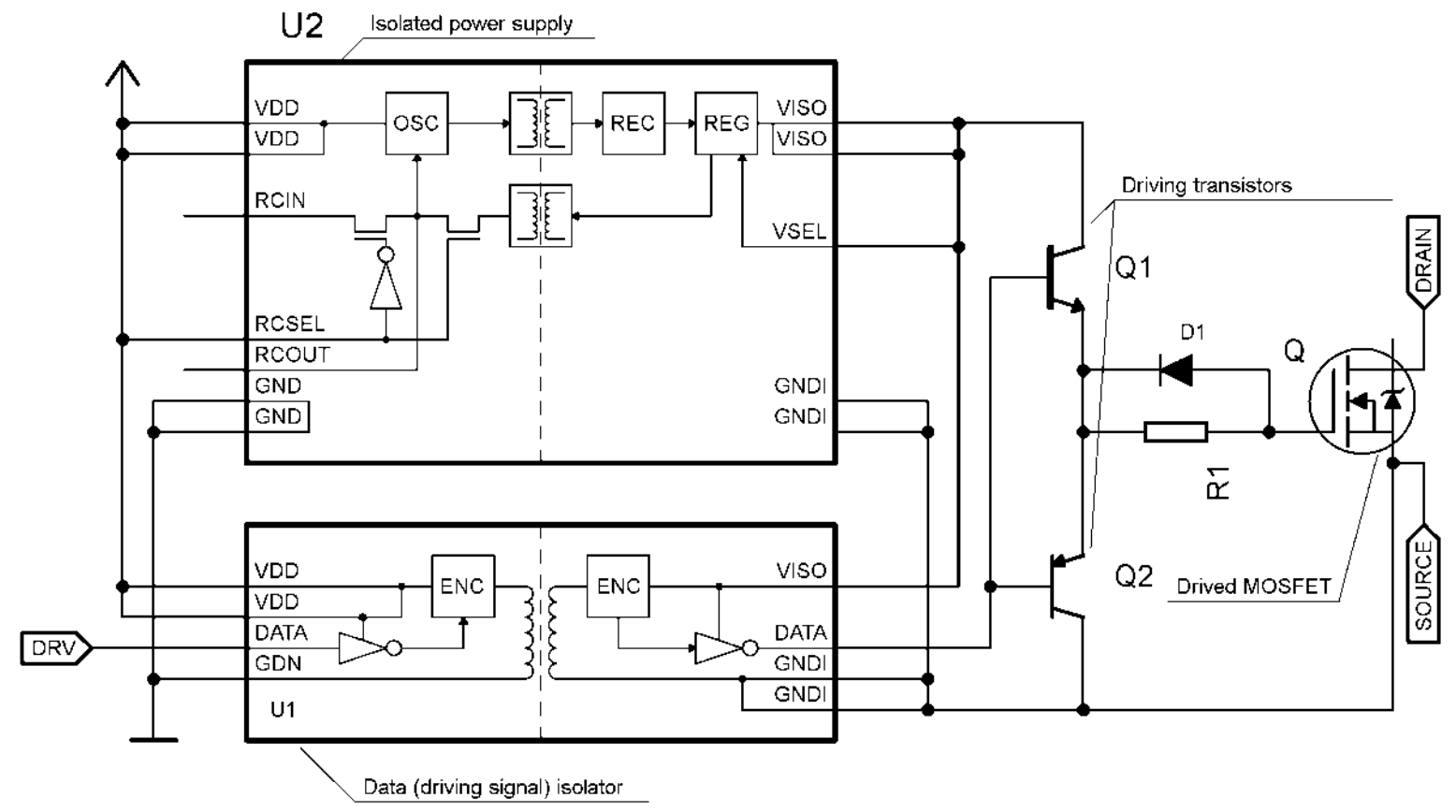

Fig. 10. Schema of driver based on utilizing of isolated drivers. ADuM5000 (U2) used as isolated power supply and circuit ADuM3100 (U1) used as a signal isolator followed by complementary pair $Q 1, Q 2$ 


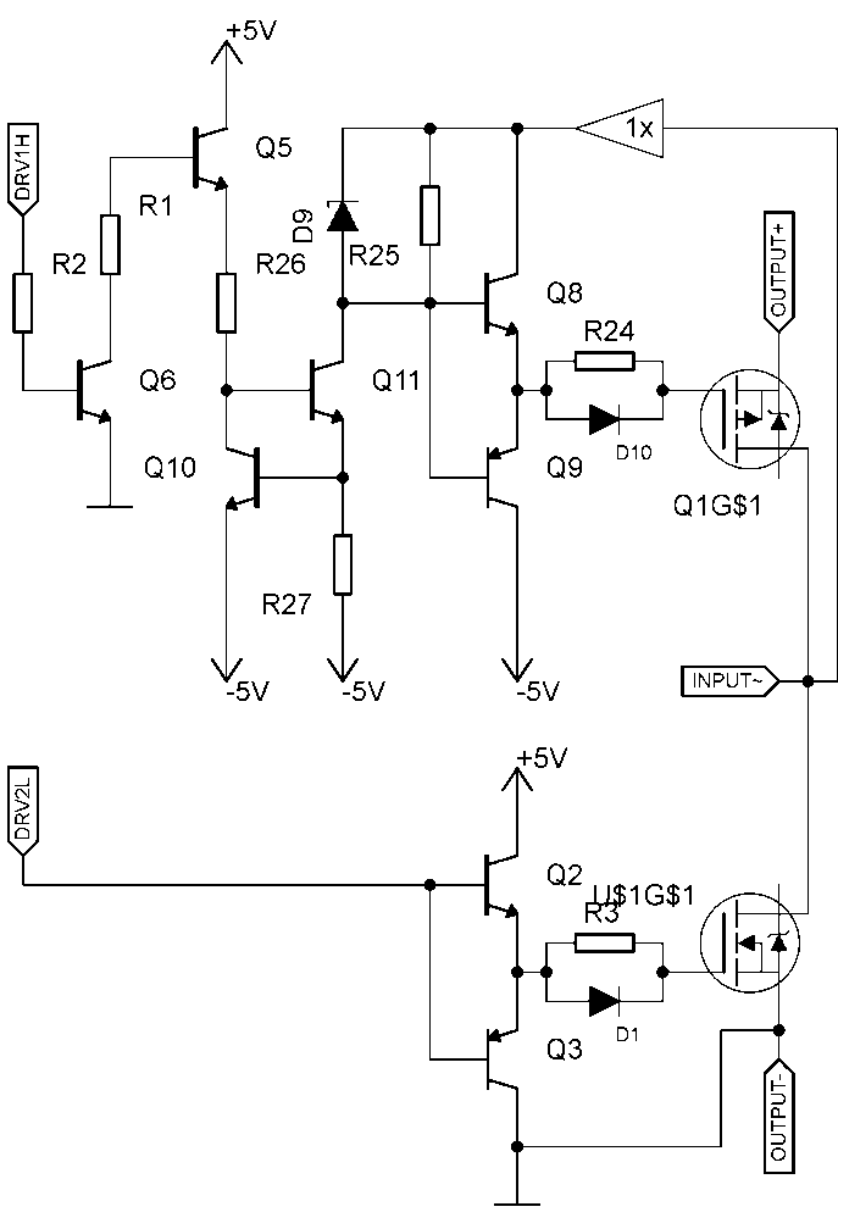

Fig. 12. Schema of driver based on buffered input voltage

Driving of high side transistor is much more complicated because of floating source. So there is as well requirement of the floating driver. Designed driver must be conformed to selected structure (P-Channel or N-Channel) of transistor. Discussed solution consists of P-Channel high side MOSFETs $(Q 1)$. There is necessary negative voltage supply for switch high side P-Channel transistor when very weak signal is appear on input of FWR. Input voltage buffer is used to prevent loading and distortion the input signal. Level shift circuit based on constant current supply (R26, Q10,Q11 R27, R25 and D9) adapts level for output complementary transistors $(Q 2, Q 3)$. This solution is more complicated but the main benefit is significantly lower cost.

\section{Conclusion}

An electronic full-wave rectifier with modified structure (Using combination of N-Channel and P-Channel MOSFETs) has been designed, built and measured. The measured prototype satisfies the stipulated conditions and targets: it reduces the current distortion and works up to $45 \mathrm{kHz}$ and $0.5 \mathrm{~A}$. Further testing will be possible after the necessary instrumentation is provided. Current tests have been done on upgraded audio amplifier working up to $45 \mathrm{kHz}$. Maximal working frequency of full-wave rectifier is determined by delay from crossing zero on the input of full-wave rectifier to the transistors occurrence in wanted state. The limitation is speed of drivers. Propagation delay of used isolators is at this time negligible.

\section{Acknowledgment}

The research described in the paper was financially supported by a grant of the BUT science fund, no. FEKT-S-11-5/1012, and the authors also received assistance from projects within the Education for Competitiveness Operative Program, nos. CZ.1.07.2.3.00.20.0175.

\section{References}

[1] Chytil, J.: Electronic diode used in bipolar electronic loads. Electrorevue, Vol. 15, No. 6, 2013, 391-394.

[2] Dabing, M., Jianli, X.: The Design of Ideal Diode. 2012, DOI: 10.1109/ICASID.2012.6325307.

[3] Linear Technology: LT4320/LT4320-1 - Ideal Diode Bridge Controller Datasheet 2013 URL: http://www.linear.com/docs/43273

[4] Analog Devices: AduM5000 - Isolated DC-to-DC Converter Datasheet 2012 URL: http://www.analog.com/static/imported-files/data_sheets/ADuM5000.pdf

[5] Analog Devices: AduM5000 - One Channel Digital Isolator Datasheet 2012 URL: http://www.analog.com/static/imported-files/data_sheets/ADUM3100.pdf

\section{Ing. Jiří Chytil \\ e-mail: xchyti06@stud.feec.vutbr.cz}

Jiří Chytil (1988) is Ph.D. student at Faculty of electrical engineering and communication of Brno University of Technology. He is researching at field of the analog design, and optimization of analog circuits. Author also works as an circuti designer for BioVendor Instruments a.s.

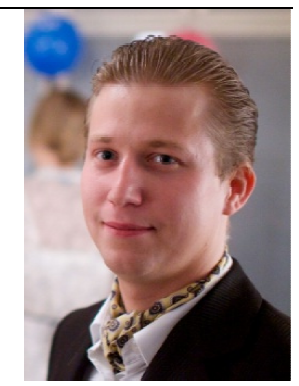

otrzymano/received: 2014.04 .09 przyjęto do druku/accepted: 2014.09 .16 